\title{
Beginning Preschool Teachers' Views Toward Mentoring Programs in Turkey
}

\author{
Özdemir Ali $^{1} \&$ Kaygısız Cansu ${ }^{1}$ \\ ${ }^{1}$ Department of Educational Administration, Marmara University, Istanbul, Turkey \\ Correspondence: Özdemir Ali, Atatürk Faculty of Education Goztepe Campus 34722/Kadıköy, Istanbul, Turkey. \\ E-mail: aliozdmr32@gmail.com
}

Received: November 20, 2018

Accepted: December 16, 2018

Online Published: January 17, 2019

doi:10.5539/jel.v8n1p182

URL: https://doi.org/10.5539/jel.v8n1p182

\begin{abstract}
The main purpose of this study is to reveal the view of preschool teachers who are in the first five years of the occupation about mentoring programs applied to them. To reveal the experiences and opinions of the teachers, the qualitative research design, phenomenology, was used. To determine the preschool teachers who are in the first 5 years of their occupation, criterion sampling from purposeful sampling methods was used. To achieve the purpose, the semi-structured interview form was applied to the teachers. The answers were analysed by using descriptive analysis approach. As a result, the teachers said that they have problems in communication and classroom management because both they are inexperienced and they are working with small age children. To overcome these problems, they develop their own ways mostly with trial and error. In addition, in the process of pre-service teachers' education, they feel lonely. In the process, they do not take any help from any experienced teacher or any other helping resources. Also, they claim that the pre-service teacher trainings do not serve for the aim, and the process is just a formality. It is offered that teachers might be adapted to the profession with the help of special professional trainings and quality mentoring programs.
\end{abstract}

Keywords: preschool, early childhood, education, mentoring

\section{Introduction}

Education is one of the most important criteria for a society's quality. A person spends a considerable amount of time in the mainstream schools. The quality of the physical environment, the education, and the teachers in the mainstream schools has a critical impact on the person's future life circumstances. In the school, quality of the physical environment and education are related with the quality of the teachers. If teachers are received the high-quality material and nonmaterial resources, they might be able to have self-actualization. Therefore, self-actualized teachers become capable of enhancing all the factors they have impact on. As it is known that the future of the society is in relation with the societies young members so it is also relating with education and the teachers who are the practical applicators of education. The value for the education and especially value for teachers shows the developmental level of the country (Gül, 2015).

In the educational system, teachers have the most vital role. They are the main element of the educational systems. It is expected from teachers that they carry the responsibility of enhancing society; raising qualified labour force and providing societal peace. Teachers need to help to individuals in order to socialize them and prepare them to the life. Beside this, they have crucial role in transferring the culture and values of the societies to the next generation (Çelikten, Şanal, \& Yeni, 2005).

In last decades, because of the changings in life circumstances, most of the children have to spend their times in the schools. Having qualified teachers is a pre-requisite for gaining sense of security and self-confidence for the children. Teachers apply the educational curriculums, manage the training process and carry the responsibility of reaching educational purposes. For this reason, effectiveness of the teacher training programs has crucial role in defining the quality educational systems (Ekinci, 2010). A teacher gains the necessary qualifications with the help of his/her own personality; quality of education that he/she got and vision of education. Beside this, support of the schools has critical importance to gain necessary teaching qualities.

Becoming a good teacher depends on two qualities. The first one is having a quality pre-service training, and the other one is to benefit from in-service resources. All of the reasons show the importance of the supporting 
teachers in every area in order to help them to develop themselves (Seferoğlu, 2004). Recently, both the modern life conditions and understanding of the importance of early childhood education lead to increase in need of early childhood education centres. Even though early childhood education is not compulsory in Turkey, schooling rate in early childhood years have been increasing day by day like all around the world.

Early childhood years includes the age of 0 to 6 . It is defined as an educational term that children complete almost all physical, socio-emotional, cognitive and also language development which has great impact on their future life (Arslanargun \& Tapan, 2011). If children spend quality time in those years, not only their school success and professional life but also individual lives will be affected in a positive way. The main task of the early childhood centres is that they have to support the children in order to gain basic life skills to have good life conditions both in today and tomorrow (Sheridan, 2001). If the children have positive experiences during early childhood education, they will gain positive attitudes toward school, learning processes and their own skills (MEB, 2013). In short, the child will invest in future with the help of quality early childhood education.

The quality of the early childhood years depends on the communication between child, family and teacher. It is a fact that the conditions which the family provide for the child and the type of the communication which they have in the home environment is a decisive factor for the quality of these years. In addition, with the spread of early childhood education centres, the quality of the early childhood years is mostly provided by these centres, especially by the teachers in the centres. One of the determinant criteria for the qualified early childhood years is that teacher's personal and professional features. A qualified early childhood centres needs component teachers (Sheridan, 2001). Children might be able to explore environment and benefit from learning opportunities if they are sure that they are cared and feel secure in the environment. Consistent and secure relation between child and teacher is the provider of this secure and caring environment (MEB, 2013).

It is seen that Turkey gives importance to early childhood education just as other developed and developing countries according to the increasing tendency to early childhood education and development in early childhood education. In Turkey, importance of early childhood education is expressed more than other school levels. Especially after 2000's governments of Turkey have given priority to the early childhood education. They allocate more quota for the early childhood education teachers in their teacher assignment list. Moreover, it is observed that educational principals and community leaders give active support for the early childhood education's ex-tensification policies (Arslanargun \& Tapan, 2011).

Today, almost in all universities which have faculty of education in Turkey, there is a department of early childhood education. Department of early childhood education covers 4 years of education which provides necessary theoretical basement and some practical experiences for the pre-service teachers. However, being a teacher needs more practical experience than theoretical knowledge. According to Bakioğlu (2015), even the teachers have lectures about learning and teaching processes and skills in the undergraduate education years, the teachers who are in the phase of initiation feel themselves insufficient in these skills. Although teachers have some practical experiences in the underground education, they mostly confront with families, school principals and community members because of some social factors in the first years of occupation. Also, they might have increased stress level and professional dissatisfaction due to the difficulty in classroom management and misbehaviour of the students (Mccarthy, Lambert, \& Watkins, 2016).

In the first year of occupation, early childhood education teachers have some questions like "Am I stay alive?"; "May I be able to turn back home without losing any child?"; "May I do this kind of job every day?"; "Will my colleagues accept me?" in their minds. They try to cope with these kinds of problems during the year. In the questioning term, teachers are in need of understanding and feeling of being supported, being comforted and being protected (Ekinci, 2010; Katz, 1972; Rust, 1984). These questions evolve in the following 5 years. Teachers start to ask some questions such as "What is the need of this child?" and "What should I expect from my students?" After a while, teachers get bored of doing the same thing in each day. They start to look for new opportunities while they are questioning their profession (Işık-Ercan \& Perkins, 2017; Katz, 1972; McCarthy et al., 2018). Teachers' stress level increases while they try to cope with these kinds of questions. As a result, most of the teachers quit the job in their first years in the profession. Sense of dissatisfaction of the teachers who are stressed lead to sense of fatigue. In the following years, consistency of these negative feelings results in leaving the profession (McCarthy et al., 2018). In this coping process, beginning teachers needs the experienced teachers to be enlightened. In other words, inexperienced teachers need mentors to cope with the problems of the first years of profession.

The phenomenon of mentoring has been mentioned for centuries. It fulfils the gap between theory and practice but there was not enough given importance throughout the years (Bakioğlu, 2015). Mentoring might be defined 
as an application of experienced people's both psychological and professional support for the inexperienced once. In the several mentoring studies, it has been said that mentor is more experienced than the mentee. There is a reciprocal relation between mentor and mentee. Mentor shares the skills, knowledge and experiences with mentee in the scope of this mentoring relationship. In the mentoring program, mentor gain new skills, knowledge and experiences as well as mentee. Thus, both the mentor and the mentee benefits from opportunities of the mentoring programs (Ambrosetti, Knight, \& Dakkers, 2014).

Mentoring programs is preferred often in the field of business, management and education. One of the most important reason for this preference is the idea that mentoring programs will make easy the transition from theory to the practice. Specifically, in the educational mentoring programs, mentors give supports about teaching and learning processes to the mentees. In the process, a mentor might follow the way of telling his/her experiences and methods in teaching. By the way, a mentor might choose the way of being a role model for the mentee in order to shed light on beginning teachers' way. Evaluating the mentee in the lecture might be another way in the mentoring programs (Ambrosetti et al., 2014).

A teacher mentor needs to have clear mind about effective teaching methods; be able to tell appropriate teaching methods according to students' qualities; be able to collaborate with inexperienced teachers in order to reduce their concerns; create the opportunities for professional development of the teachers (Watkins, 2016). Teacher mentors are advisors for the beginning teachers in paper works, communication with parents and their own professional development. According to Işık-Ercan and Perkins (2017), in the field of early childhood education, mentoring programs need to focus on children, family and teacher relations; documentation of learning and practice; self-evaluation; activity plans and skill development.

Preservice programs are critical for the teacher training progress. It is because the process covers the programs of preparation for occupation. Also, in the process, preservice teachers are intensely meeting with the teaching practice (Ekinci, 2010). If the issue is considered in the case of Turkey, newly nominated teachers works as a pre-service teacher in the first year of their profession. Pre-service process includes the performance evaluation, exams and follow-up applications. The process lasts in 1 year. In a year, it is aimed that beginning teachers gain knowledge and experiences about profession in relation with mentoring programs. The nominated teachers have seminars and several practical services under the name of pre-service programs in the scope of mentoring program. Turkey's pre-service training programs for teachers are similar with the mentoring programs of developed countries (Ulubey, 2018). Pre-service teacher needs to have social relationship with school principals, colleagues and school environment in order to gain positive perspective toward profession and working atmosphere. Thanks to the relations, beginning teachers also gain basic professional skills (Ekinci, 2010).

Turkey's Ministry of Education issued a directive about pre-service teachers' training program in 2016. According to the directive, program which prepared by Ministry of Education is applied by school principal and advisor teacher in the school which pre-service teacher is nominated in. According to sentence, mentoring includes both the ministerial program, school principal and advisor teacher. In the school which pre-service teacher is nominated in, there is a practical training program. For this aim, a teacher who has at least 10 years teaching experiences is given responsibility to be an advisor teacher. Pre-service teacher might enter the courses with the advisor teacher. Moreover, school principals control the course of events during the process. Advisor teacher cooperate with the school principal in order to make provision for application of the scheduled practical program (Elbay, 2015).

To sum up, it is important to have quality mentoring programs for the beginning teachers until adapting to the school environment and occupation. Katz (1972) mentions that a pre-school teacher's adaptation actualizes in the first 5 years of occupation. However, in Turkey, pre-service teacher training program lasts in 1 year. Then there is no other mentoring program is provided for the teachers. It might be said that the teachers are left alone in the classes suddenly. In that case, their adaptation process is also left half-finished. Therefore, decrease in the quality of education becomes unavoidable. Nevertheless, if a country has quality education, the future of the country will be affected in a positive way. Therefore, it is important to deeply find out the problems in mentoring programs for the teachers in order to make contribution to quality level of education in Turkey

In the field of study there are many studies about teacher mentoring and application of it. However, there is not enough study specifically teacher mentoring in the field of early childhood education. That is why it is thought that the study will find out the functional and dysfunctional aspects of the applied teacher mentoring programs in the field of early childhood education. Therefore, the study will contribute to the related field studies and shed light on the future studies. In the research, it is aimed to deeply analyse and find out the views of the pre-school 
teachers who are in the first 5 years of occupation about mentoring programs which they are included in. For this aim, it is intended to answering following research questions:

- What are the opinions of the pre-school teachers who are in the first 5 year of the occupation about occupation?

- What are the problems and solutions of the preschool teachers who are in the first 5 year of the occupation during the process?

- Are the preschool teachers who are in the first 5 year of the profession aware of the mentoring programs that they are included in?

- How the preschool teachers' who are in the first 5 years of occupation evaluate the mentoring programs that they are included in?

\section{Method}

\subsection{Research Design}

In the study, in order to deeply analyse and reveal the participants' views and experiences about related field, the phenomenology one of the qualitative research design was used. Phenomenology studies defines the shared meaning of the experiences about a phenomena or notion by people (Creswell, 2016). The design of Phenomenology is focused on the phenomena which people are aware of but do not have deeply understanding about it. People may confront with the phenomena through several ways like experiences, perceptions, tendencies, notions and situations. Phenomenology studies prepares an appropriate working base for the studies which aim to study the phenomena which people are not totally strange to but at the same time could not exactly comprehending (Yıldırım \& Şimşek, 2016).

\subsection{Participant Group}

Criterion sampling which in one of the purposive sampling was used in the research. Purposive sampling means that the researcher chooses the participants and places for the study. It is because participants might be willing to give the needed information in order to understand the phenomena which is in the centre of study. There are 3 aspects for the using purposive sampling approach in the qualitative research design. These aspects changes according to features of the approach. These aspects are the decision for who will be chosen as a participant, what are the specific sampling strategies and decision for the size of the sampling group (Creswell, 2016). Criterion sampling is based on important criterion, all cases that meet the criterion are studied, implicitly comparing the criterion cases with those that do not manifest the criterion (Patton, 2015, p. 576). The basic criteria for this study is that participant pre-school teachers must be in the first 5 years of their occupation. In this manner, participant group of the study includes the pre-school teachers who are in the first 5 five years of their occupation and who are working in the public early childhood centres during 2017-2018 educational year. There are 7 pre-school teachers in the study. All participants are women. Teachers are working in 3 different public schools in Istanbul. 1 participant is in the first year; 1 participant is in the second year; 1 participant is in the third year and others are in the fourth year of the occupation. The ages of the participants are in between 23 and 28 . The table for participants is given below:

Table 1. Personal information of the participant teachers

\begin{tabular}{lllll}
\hline Participants & Gender & Age & Years of seniority & Working years in that school \\
\hline T1 & Woman & 28 & 4 & 3 \\
T2 & Woman & 26 & 3 & 3 \\
T3 & Woman & 23 & 1 & 1 \\
T4 & Woman & 27 & 2 & 1 \\
T5 & Woman & 28 & 4 & 4 \\
T6 & Woman & 27 & 4 & 2 \\
T7 & Woman & 27 & 4 & 2 \\
\hline
\end{tabular}

\subsection{Instruments}

In the study, a semi-structured interview form is used in order to reach to views and experiences about mentoring programs which applied for beginning teachers. The questions in the form is prepared by the researcher. Applicability of the questions was controlled by the experts in the field. In the approach, interviewer has the 
freedom of asking both prepared questions and related additional questions in order to get detailed answers from participants (Yıldırım \& Şimşek, 2016).

\subsection{Data Collection and Analysis}

Interview is a method of having the quality information through conversation with a person who has the needed information. In a quality interview, the questions incentive for the interviewing person to talk. An interview is a communication and relation and at the same time it is an observation (Patton, 2015, p. 896). In the research, interviews are done face to face. In order to get complete and deep information, sound recording was used. One of the participants did not let the recording so the answers of the participant is written by interviewer. Average interview duration was nearly $20-25$ minutes.

The analysis of the data is done by using the descriptive data analysis which is one of methods of qualitative data analysis. The data is summarized and interpreted regarding the research questions. Views of the beginning teachers are examined and relevant views are collected under the pre-codes. After reconsideration of the codes, categories, sub-themes and themes are prepared by taking the scientific research process into consideration. In the Alpaydin (2018), it is seen that for the descriptive data analysis the same steps are used. In that study, views and expectations of the participants are analysed and codes are attained. With the re-evaluation of the codes, the themes are obtained. The aim of this kind of analysis is to serve the findings in an order and as interpreted to the readers. For this end, data is described in a systematic and openly way. Then, these descriptions are explained and interpreted. The cause and effect relations between the findings are questioned. Lastly, researcher achieves some results. Researcher might relate the revealed themes and interpret them. Also, researcher might make predictions with the results (Yıldırım \& Şimşek, 2016).

\section{Findings}

In the research, 8 questions were asked to participants in order to take their views about mentoring programs. Acquired data was analysed according to research questions. At the end of the analysis, findings were revealed.

\subsection{Views about Occupation}

In order to understand the pre-school teachers' opinion about occupation, the question that "What is your views about occupation and work life?" is asked. According to participants' answers views about occupation theme is constituted. Related table is placed below.

Table 2. Views about occupation

\begin{tabular}{lll}
\hline Theme & Code & $\mathrm{f}$ \\
\hline Views About Occupation & Reason to like the occupation & 3 \\
& Served Personal Benefits & 2 \\
& Served Occupational Benefits & 2 \\
& Requisites for doing Occupation & 1 \\
& Negative Views about Occupation & 3 \\
\hline
\end{tabular}

Participants teachers shared their views about occupation. According to acquired data, 3 teachers shared why they like the occupation. All of the three teachers said that they like the occupation because they like the children. Views of $\mathrm{T} 5$ and $\mathrm{T} 6$ as follows:

"It is a tiring job but it is also nice because I love children." (T5)

"I chose the early childhood education because both I love the children and wonder how can I be a good mother; how can I be conscious mother. That's why I chose the occupation." (T6)

It has been understood that teachers think that occupation offers some personal benefits. Teachers might have both time for themselves and skills to be a mother thanks to the profession.

"I think that being a teacher is a meaningful job. It is a big chance that I can allocate some time for myself thanks to the occupation." (T1)

Maybe I have a child in the future and he needs a better mother, that is why I studied in department of early childhood education." (T6)

It is mentioned in the data that during the occupational life, teachers learn how to work collaboratively and how to work with children from different developmental levels. The participants T2 and T4 mentions their opinions about occupational benefits as 
"We collaborate and corporate with other teachers so we can organize better workouts. That's why my opinions about occupation is positive" (T2)

"The greatest occupational benefits of this year are that I have a child with a down syndrome. Last year I did not have any inclusion child in the class, this years' greatest experience is this child for me." (T4)

T7 expressed the requisites for doing the occupation. Her opinion is like

"Being a preschool teacher needs a lot of patience and devotion. That's why it is not an occupation that you do not like. You are in relation with youngest children. They are not in the same place with the other level of teaching groups. That's why you have to like the occupation."

At the end, 3 participants mentioned the negative opinions about the occupation. They think that the job is tiring. Also, it is understood that their negative opinions are mostly related with the communication with both families and school principals."

"I cannot say my opinions change in a positive way. We cannot educate the children because we try to fiddle with families. Also, oppressive attitude of the school principal caused in negative image of the occupation for me." (T2)

"It is a tiring job but it is also nice because I like the children." (T5)

"Working life is intensive and tiring. Communication with families would be tiring most of the time." (T7)

\subsection{Occupational Problems and Solutions}

In order to understand what are the problems and stress factors which participants confront with in the first years of occupation and solutions for these problems several questions were asked. these questions are "What are problems/stress factors that you are confronted with in the first years of occupation" and "What are the solutions in order to cope with these problems; eradicate the stress factors?" according to participants answers table 3 is prepared and placed below.

Table 3. Occupational problems and solutions

\begin{tabular}{llll}
\hline Theme & Sub-Theme & Code & $\mathrm{f}$ \\
\hline Occupational Problems and Solutions & Confronted Problems & Personal Reasons & 4 \\
& & Limited Physical Resources & 2 \\
& & Problems in School Directory & 2 \\
& & Ages of the working group & 2 \\
& \multirow{3}{*}{ Solutions } & Family Communication & 2 \\
& & Cooperation & 7 \\
& & Personal Effort & 6 \\
\hline
\end{tabular}

Participants have been confronted with several problems through the first years of occupation. They have found some coping ways for the problems. Firstly, problems of teachers were analysed. Teachers intensely relate the problems with their personal situation. In the topic, the most expressed idea is being inexperienced.

"When there is a problem and I think that what should I do in this situation, I try to solve the problems with my knowledge from university and practicum sites." (T2)

On the other hand, T5 expressed the personal situation because of the deficiency in university training. Her idea is like

"Mothers are more problematic than children.... Also, university training is not enough. Training which we have is all about children. Actually, in the university years there could be courses about communication with parents.... When I was an intern, every day I had great headache. I thought that I cannot do this job. However, being an intern and actual teacher of the class is different than each other. When you become an authority in the class, children realize it. They could exploit you as an intern."

Two of the teachers mentions that there are some problems because of the limited physical resources.

"When I was in compulsory service in the eastern part of the Turkey, I had stress because of the limited resources." (T1)

"I have problems because I have limited place. I have really small classroom. For the children, it is a small place to do some activities and play in." (T5) 
About the subject matter, 2 of the teachers expressed that they had trouble with the school directory in the first years of occupation. Their views as follows:

"He always summons me to his room. Then he always criticized me. Unhappily, it was not a positive way of criticizing. It was a devastating criticizing. Sometimes, I was affronted by him during conversation. This attitude drove me into stress."

"In the first year of occupation, my school principal said to me that there are 2 groups. One is the group of 3 years old children. The other one is the group of 5 years old children. Then, he asked that which one do you prefer? I replied that I want the group of 5 years old children. At the end, he gave me the group of 3 years old children. It was a disastrous year." (T7)

Teachers also have problems in communication with parents as it can be understood from answer of T6. The answer was like

"I had problems in parent communication. Everybody thinks that their children are better than the others. They think that my child learns better than the others' child. That's why we have family factor in the occupational problems." With the answer she mentions the stress factors related with problems in parent communication.

The participant T4 mentions the problems caused by working with small age group. The idea is specific for this occupation and it was like

"I worked with the group of 3 years old children in my first year of occupation. That's why I had difficulty in working. In this age, children are still depending on mother. Because they are so young, they cry a lot. The group of 3 years old children were really difficult for me."

\subsection{Views about Mentoring Programs}

In order to deeply understand and analyse the views and evaluations of the participants toward applied mentoring programs, several questions are prepared according to pre-service teacher training directive of National Ministry of Education in Turkey. The questions were "How do you describe your communication/relation with your school principal and advisor teacher?"; "What are the ways that your school principals and advisor teachers follow in order to adapt you to the occupation?"; "As a beginning teacher, do your school principal or advisor teacher shows you a solution of the problems that you are confronted with? What should do they do for this aim?" Also, in the scope of mentoring in Turkey, pre-service teachers have some in-service trainings. In order to reveal the views toward these trainings the questions of "What are your opinions about in-service trainings which are organized by Ministry of National Education for pre-service teachers? and "What are the resources that you received throughout pre-service trainings?" were asked to the participants. With the acquired data, table which placed below is prepared.

Table 4. Views about mentoring programs

\begin{tabular}{|c|c|c|c|c|}
\hline Theme & Sub-theme & Category & Code & $\mathrm{f}$ \\
\hline Views about & Relation with Mentor & Way of Communication & Formal & 4 \\
\hline \multirow[t]{20}{*}{ Mentoring Programs } & & & Open and Objective & 3 \\
\hline & & & Cooperative & 2 \\
\hline & & & Problematic & 2 \\
\hline & & & Informal & 1 \\
\hline & & Occupational Guider & Mediator & 4 \\
\hline & & & Educational Contributor & 4 \\
\hline & & & Suggestive & 3 \\
\hline & & & Coercive & 3 \\
\hline & Pre-service Teacher & Critics & Systematic & 5 \\
\hline & Training Process & & Training & 3 \\
\hline & & & Psychologic effects & 2 \\
\hline & & Received Resources & None & 4 \\
\hline & & & Labour Union & 2 \\
\hline & & & Mentoring & 1 \\
\hline & Suggestions and & Expectations from & Helping in Practice & 3 \\
\hline & Expectations & Mentor & Mediation & 1 \\
\hline & & & Psychological Support & 1 \\
\hline & & Toward training process & Advisor teacher & 3 \\
\hline & & & Seminars and resource books & 3 \\
\hline & & & Description for responsibilities & 2 \\
\hline
\end{tabular}


With the help of related questions, participants' views about mentoring programs are taken. It seems that teachers answer the questions in relation with their school principals. In other words, they did not mention the existence of advisor teachers. They solely explained the way of communication with their school principals. They mentioned that they have communication with their school principals in an open and objective way. Their relation is lying on cooperation. Also they used both formal and informal way of communication. On the other hand, some of the teachers see their relation as a problematic with the school principals. 4 of the participants describe the communication way as formal communication. Their views about subject matter as follows:

"He helped me. He introduced me to the other teachers. He always asks me that is there any problem?" (T3)

"He stated clearly what he expects from us. You have to do it. We could not confront with him if we did not complete the task. He had the authority upon us. He planned everything." (T4)

Participants expressed their open and objective communicational experiences with their school principals. In this manner, some of the participants' view as follows:

"We have a really good communication with him. I could say what I want." (T4)

"Our school principal is an objective man. He always takes the other teachers' opinions. He gives value to the teachers. Of course he wants peaceful school environment so that he gives effort for this aim." (T7)

The participant called T1 mentioned that she has cooperation with her school principals. Her statement as:

"We are in a positive relation in general. I have to participate in university lectures during the week. In this manner he is flexible. Therefore, I actively take role in the organizations and several activities in the school."

However, the participants T2 and T7 mentioned that they had problems in communication with school principals in the past as follow:

"As I mentioned before he mobbed us. Because I was a beginning teacher, I did not know who I can consult or I can tell my problems." (T2)

"It doesn't matter whether there are any parents or not in the room. If there is an issue, he reprehended us in any way. Unfortunately, this attitude decreased the teacher motivation. He doesn't able to solve any problem. He drove you directly into a problem, then he wants you to cope with this problem alone." (T7)

Participant teachers explained the mentor roles in the vocational counselling. Ideas of the teachers were collected under the codes of mediator, educational contributor, suggestive and coercive. 4 participant teachers referred to the social contributor role of the school principals like:

"He organizes motivation dinners monthly." (T1)

"When I came to school for the first time, he introduced me to other teachers and school staff." (T7)

At the same time 4 of the participant teachers mentioned that school principals take the role of educational contributor. In other words, they said that their school principals support their occupational development in many ways.

"When it is needed our school principal direct us to the seminars, then we join several of them."

T3, T4 and T6 mentioned that their school principals counsel them most of the time.

"He informed us about school atmosphere, working and going of the school. He also directed us to the needed fields." (T4)

"School principal always talked about the working of the school. He told me that it is done by this way but you can also choose another way that you want." (T6)

Lastly, 3 of the participant teachers mentioned that school principals are coercive instead of being supportive.

"School principal always pushes the teachers to do his personal jobs with the calling them to school even early in the morning. Nevertheless, we were working hungry. Thus, I can say that from the early in the morning to the evening, I fed some silly people's ego." (T2)

"School principals never take stand for the teachers. students and parents were always right in any issue. That's why they said that you have to be careful every time in front of students and parents. He resisted to the teachers' expectations. He never supports the teachers. Moreover, he was always self-opinionated." (T6)

When the questions which are prepared to take the participants views about pre-service teachers training process were analysed, it is understood that all of the teachers criticized the process. These criticisms are toward system, 
training process and the psychological effects of the training process. In this manner, some of the participants' criticism about system is like

"We became a teacher after passing many exams and internship process. However, I guess that you cannot be a nominated teacher before 4 years of experiences now. For me, it is not fair despite all of these difficult exams and internship programs." (T1)

"I disagreed that the examination system for the teachers. Maybe, interview would be more appropriate. Exams are just based on memorization. You memorize the book until exam, then you forget everything. Therefore, it is not sufficient progress." (T4)

One of the participants summarizes the all criticisms about pre-service teachers training progress with these words:

"The process was red tape. It was done because it had to be done. We repeat all of the topics which we had in the courses of educational sciences. Topics were in general. It was all mixed that there were high school teachers, primary school teachers and preschool teachers in the same seminars. It was all wrong process. In my opinion, seminars should be special for majors. In my seminar class, high school teachers have the problem of addictions to the cigarette and other drugs. However, my problem was separation of the child from mother." (T5)

T3 and T6 mentioned that the process impacted on their psychology. Their words about the subject matter were like

"There are many stress factors because of self-problems, exams, interview and become nominated or not. They are all stress factors for me." (T3)

"We do not know what is our rights as pre-service teachers. Moreover, we keep clear of questioning. We are afraid of to question it because we do not know what will happen after all. In the seminars, teachers' suspicions might be discussed. They might help us. We have worry for our situation in the future." (T6)

With the help of relational questions, participant teachers mentioned their opinions about resources that they received during process. According to answers, it is seen that 4 of the participant teachers said that they did not receive any resources during the process. 2 participant teachers mentioned about role of the labour unions in the process. Only 1 teacher mention about the appearance of the teacher mentor in the process. In this manner 4 of the teachers mentions that there is any received resource during the process.

"We had interview with the educational inspectors. They were 4 or 5 people. Maybe there were an advisor teacher with them. We answered the questions then the results were published on the internet. I even do not know who is the advisor teacher. In the process, we were not informed about advisor teachers." (T4)

By the way, T2 and T4 mentioned the role of the labour unions during the process. Their statements about the subject matter were as follows:

"After I talk with a teacher about my problems with school principal, he said that there is labour union. Until that time, I did not know anything about labour union. Then I became a member of union. I had a resource in this way. People in the union supported me, then my school principal give up to be coercive upon me." (T2)

"We bought our labour union's book and we studied it. It was really effective." (T4)

Lastly, only one participant mentioned that she is aware of the teacher mentor. Her words were like:

"When I was a teacher in the village, somebody talked about mentoring program but she just came to school once. That was how the program was applied to us."

Teachers have some expectations from their school principals and experienced teachers in the school environment. These expectations are for adapting to the occupation. They also gave some suggestions what there should be in the process. These are expectations from mentor and training process and suggestions for the training process. First of all, teachers expect that their school principals could be helpful in practice, contributor with the school environment, and psychologically supportive. Also, teachers give some suggestions about efficiency of university programs. Beginning teachers mentioned that they are in need of practical support of the experienced teachers and school principals. They give some suggestions as follows:

"Teachers could be supported during pre-service teachers training process. However, our job is based on practice than the theory. We can learn the job with the practice. Advisor teachers should be work actively. Therefore, it would be meaningful when they could interfere in our problems." (T1) 
"You came to class with a lot of theoretical background but you have a lot of difficulty in class management. If you do not transit your theoretical background to the classroom, it lost all the meaning. In my first year, I had really active children in the class. Mentor could come to my class and be a role model for me." (T2)

Also the same participant wants to see the school principal as a provider of communication with other teachers.

"He could provide to entering other teachers' classes for us. With these words she wants to see her school principals as a provider of communication with other teachers." (T2)

Also one of the participants expects that the school principal might reconcile the teachers with parents. Her statement about the expectation was exactly like

"He could say that okay, you are right! If there is such a problem, we can invite the parents to the school and do something." Some participant teachers also expect the psychological support of the school principals. (T6)

In this manner, teachers mentioned their expectations from university programs. They see the undergraduate programs inefficient. One of the participants' views about subject matter as follows:

"I expected the support of school principals in my first year. You were graduated from the universities, then you directly entered the classroom and parents' environment. However, this is the issue of universities rather than pre-schools. It's because working place is late to talk about this. You are directly into the situation. You have no chance to say that I don't know this because I just nominated to the job." (T5)

For the pre-service teacher training process, participant teachers' suggestions were about received advisor teacher, received supplementary resources and books and explanations of the tasks and responsibilities of the pre-service teachers. Some opinions of the teachers are given like.

"To make easy the process, there would be two teachers in the classroom. I could be with the experienced teacher." (T5)

A participant teacher expects both advisor teacher and supplementary resources during the process. Her opinion is like

"As a supplementary resource, as I said before we could have advisor teacher, also we could be given the books which advisor teacher uses." (T7)

At the same time, some participant teachers suggest that principals could explain the tasks and responsibilities of the pre-service teachers.

"What is the job statement? Somebody could say that these are your tasks and responsibilities. My expectations are these from you. You should read and learn them." (T2)

"Before nomination, they can organize a meeting and talk about going of working. They can inform us what we will confront with during the process. They might talk about what will be next step. Or they can evaluate the process." (T6)

\section{Discussion}

After the analysing the views of pre-school teachers who are in the first 5 years of occupation, it is understood that this major is different than other teaching majors. The idea that it is tiring and abrasive occupation because there are really small age group children so the job cannot be done without loving the kids is forehead. According to participant teachers, loving the children is a must for doing the job. In the international literature, it is mentioned that early childhood education centres differ from primary schools with the feature that children who are in the age of 0 to 5 needs more attention and compassion. Also, it is necessary to give education to these ages children. Relating with the difference, importance of resources quality, curriculum and programs in the early childhood education programs gain importance (Brazil, 2013; Kelly \& Berthelsen, 1995).

Participant teachers indicated that they have problems in the first years in communication with parents, communication with school directory. Also, they had difficulty because they have small children and limited physical resources. They claimed that these difficulties have drove them to the stress. Most of the participant teachers relate their problems with their naivety. This naivety results from lack of practice in the university years. However, this inefficiency could not be understood solely in the classroom until teachers begin to occupation. According to Köse (2016), there is a similar result with the study. The result was revealed that theoretical base and internship programs in the universities are inefficient for the pre-service teachers to gain experiences and to do the occupation. This result of the Köse (2016) expressed that there is a need of mentoring programs in the working field. 
Difficulty in communication with parents and school principals or having limited physical resources could be problems for all teaching majors. Çelikten et al. (2005) mention the importance of physical resources in the school environment. In the article it is mentioned that to achieve the target success in education, some conditions must be fulfilled. These conditions are supplying necessary educational equipment's and preparing needed physical facilities. Starting from this point of view, it is a normal situation that teachers who wants to give quality education in their classes drive into a stress while they do not have enough physical resources. Denham, Bassett and Miller (2017) mention the stress factors of the preschool teachers in the school environment. These are long working hours, not having compliments from parents or experienced teachers, inefficiency in physical resources and sense of uselessness. This result is coinciding with the study.

In the study, participant teachers also mentioned that small age working group makes them stressful. This stress factor might be evaluated as a special factor for the pre-school teachers. It is understood that participant teachers were at lost because of the small age children. especially, they have difficulty while they are trying to apart the children from the mothers and securely bond with the children. In the Brazil's (2013) study, it is mentioned that the age group of children and class differences give rise to teachers' stress.

In the study of Ulubey (2018), the importance of the teacher mentor for the beginning teacher has placed in. It is said that observing the mentor teachers' attitude toward students, way of communication and skill of problem solving might be beneficial for the beginning teachers. Besides, pre-service teachers might have knowledge about way of communication and relation in the class with the help of observation of relation between students and teachers. Observations in the class might enhance the teachers' skill of activity planning, practice, evaluation, communication and directing the students' behaviours. These kinds of applications in the pre-service teacher training programs are important because they help not only to fulfil the need of teaching experiences but also to eradicate the need of occupational practice of the beginning teachers. In the study, beginning teachers mentioned that they are facing with some kind of problems. In order to cope with these problems, they seek help from experienced teachers and school principals. This result is coinciding with the study of Geng, Midford and Buckworth (2015). In the study, it is mentioned that early childhood education teachers expect more structured and high-quality guiding from their mentors in the process of solving the problems.

Participant beginning preschool teachers mentioned that the use their own solutions in order to solve the problems. This result cause to think that there is a problem in mentoring process. According to report of SETA "Report of Monitoring and Evaluating the Model of Training Pre-service Teacher in Turkey", advisor teacher is a critical factor of the training pre-service teacher programs. Pre-service teachers are under advisor teacher supervision in the first part of the training process. Therefore, it could be understood that advisor teacher has to be a part of the process. However, in the study, just one teacher mentioned that she had mentor during the process. However, the same teacher expressed that this was not a functional application. In the literature, Kardos and Johnson (2010) determined that pre-service teachers always faced with the mismatch of mentor-mentee. Thus, most of the pre-service teachers were not observed by mentors. Moreover, they did not have chance to discuss with the mentors about teaching process.

In the results of the study, it is understood that because participant teachers did not have chance to have enough practice in the university years and also does not have quality mentoring, they claim that having qualified teacher skills comes with experiences. It is because they tried to solve the problems with their efforts during the first year of occupation. The teachers who are not under the supervision of experienced teacher develops some methods based on trial and error like ignoring the problems, changing the educational methods, and finessing the parents toward the problems. However, if the pre-service teachers enter the class under the supervision of advisor teacher; observe the different teachers in the classes; learn the working school procedures without taking any responsibility; follow the school principal in the process, this will prevent the possible trial and error learning (Tunçbilek \& Tunay, 2017). Some of the participant teachers are frustrated by difficulties in the first years of occupation. They think that these difficulties are acceptable; every teacher might have the same problems. That's why they did not expect any help or support from others.

In Turkey, organizing the mentoring programs is the responsibility of school principals. School principal and nominated advisor teacher by school principal has to be role model for the pre-service teacher. Even though it is understood that school principals did not do the right and appropriate choosing of the advisor teacher, participant teachers see their relation positive with their school principals. According to Cantimer (2008), the responsibility of school principals is not solely informing or dispatching the teachers. At the same time, he/she has to be tolerant in order to solve the problems. Attitudes toward school principals and quality of the works will be differentiated when school principal give value to the teachers. With this way, solutions for the problems may be found easily. According to Balkar and Şahin (2014), participant educators express that mentor should have the 
skills of being cooperative, reliable, emphatic and communicative. In accordance with these studies, in this study participant teachers mentioned that they have collaboration with their school principals in a way of open-transparent, formal or informal communication. At the same time, school principals take the role of giving some suggestion about how to act in the school environment; organizing social activities; helping to meet other teachers or helping to connect with parents. Relevantly, in the Naillioğlu Kaymak (2017), it is found out that pre-service teachers are in relation with the mentors throughout picnics, dinners, touristic trips, sports matches, seminars out of school, breakfasts, home visits, teachers' day celebration etc. In contrast with the common thoughts, some of the teachers have the idea that their school principals have oppressive and coercive politics toward them. Therefore, they claimed that the attitude decreases the motivation of teachers. Similarly, it is understood that pre-service teachers have negative view toward the guiding role of school principals. It is determined that school principals were not helpful for the pre-service teachers during the process. Also they did not allocate time to self-learning process (Ulubey, 2018).

At last, participated teachers were asked about pre-service teacher training process. After analysing of the data, it is understood that all of the participant teachers criticize the training system, quality of the training and psychological effects of the process. In the study of Okutan and Aydoğdu (2009), it is mentioned that participant teachers did not satisfied with the pre-service teacher training program. During the program, participants take the course of Turkish Literature, Grammar, History. However, these courses were taken during the all educational life by participant teachers. Therefore, they see the process as a waste of time. In this study, participant teachers also mentioned that the courses in the process are the same with the subject matter knowledge.

Furthermore, the teachers claimed that they did not received any supplementary resources during the process. Some of the participant teachers mentioned the role of the labour unions during the process. It is understood that labour unions not only guiding the pre-service teachers with several resources but also passivate the coercive school principals.

In the SETA report (2017), participant teachers were asked about whether the coordinators or district directorate of national education have an active role in the process or not. A considerable amount of participants were hesitant. Small amount of the teachers claimed that they did not take active role. In this manner, a considerable amount of hesitant participants indicate that they are not aware of the roles of member of district directorate of national education and coordinators. Likewise, in this study, participant teachers said that they were not informed efficiently about the process. They claimed that the trainings which are organized by district directorate of national education are not functional. Moreover, trainings were perfunctory. Crowded training class with the teachers from different majors might be cause for developing this view of the teachers. Relatedly, participant teachers expressed that they could not find any respondent for their problems that they have in the classes. Similarly, with the result, it is determined that pre-service teachers were not informed efficiently about training process; members of district directorate of national education did not take care of the pre-service teachers sufficiently. This situation leads to the development of the idea that trainings out of the school does not have any impact on the teaching experiences (Ulubey, 2018).

Participant teachers gave some suggestions about expected attitudes and activities which they want to participate in the process. Suggestions are focused on the role of the school principals because they did not have any advisor teacher during the process. Because the teachers are inexperienced and have begun to occupation recently, they wanted that school principals should be a role model for the classroom management and parent's communication. Moreover, they expect that school principals need to be mediator both between other teachers and beginning teachers and between families and beginning teachers. At the same time, the teachers are in need of both physical and psychological support because they face with a lot of difficulties in the first days of the occupation. Expectations of the advisor teacher give some clue about something going wrong during the process.

Teachers are hesitating about having an advisor teacher. It is because they think that it could be helpful to have an advisor teacher when they start to occupation. On the other hand, they thought that having an advisor teacher might be an obstacle to become an independent teacher. However, when the study of Köse (2016) is analysed, it is understood that working with school principal and advisor teacher actively is educationally positive attitude. It is because preservice teacher will have chance to observe the expert teacher in the class; to see how the school process is going; to know school environment and students; to learn how to prepare activity plans and educational materials. In this study, teachers have the idea in contrast with the general literature. Maybe, it is result from having any advisor teacher during the process. They did not have appropriate experiences about the issue. Besides, teachers expected that some supplementary resources and seminars should be served during the process. Also they are in need of explanations what are the tasks and responsibilities they have during the process especially from members of district directorate of national education. 
As a result, evaluated data show that participants have some problems special for field of early childhood education. It is understood that age of the children creates several stress factors for the participants in doing their jobs. Besides, participants also have some problems which might be generalizable to other teaching majorities like problems in communication with parents, classroom management and limited physical resources. With the help of the collected data, it is found out that participant preschool teachers feel alone in the process of solving these problems. They try to find their own ways with trial and error in time. Also, participants mostly discuss the inefficiency of the pre-service teacher training programs. They claim that pre-service teacher training programs do not provide special learning and discussion base according to profession. However, it is also mentioned that during the adaptation for the occupation, they are in need of help from both their principals and experienced teachers in the school. These findings indicate that participant teachers do not evaluate the offered mentoring programs as sufficient. According to study findings, it is suggested that participant pre-school teachers need to spend time with people who experienced the similar problems through right and appropriate mentor-mentee matching. During the process, effective seminars might be organized and supplementary resources might be prepared and given for beginning teachers. Because participant teachers are suspicious and have prejudices about pre-service teacher training process, applications in the process might be reviewed and reformed. In short, if pre-service teacher training programs which is special for the profession and quality mentoring programs were provided for the beginning teachers, the adaptation process might become easier and enriched. It might be said that quality adaptation of the teachers might decrease the stress level of teachers. Then it probably affects the quality level of education in their classes.

\section{References}

Aday öğretmen yetiştirme sürecine ilişkin yönerge. (2016, March 2).

Alpaydın, Y. (2018). Eductional experiences of the international students in graduate programs in Turkey. Journal of Education and Learning, 7(2), 89-99. https://doi.org/10.5539/jel.v7n2p89

Ambrosetti, A., Knight, B. A., \& Ve Dekkers, J. (2014). Maximizing the potential of mentoring: a framework for pre-service teacher education. Mentoring and Tutoring: Partnership in Learning, 22(3), 224-239. https://doi.org/10.1080/13611267.2014.926662

Arslanargun, E., \& Tapan, F. (2011). Okul öncesi eğitim ve çocuklar üzerindeki etkisi. Abant İzzet Baysal Üniversitesi Ĕ̈itim Fakültesi Dergisi, 11(2), 219-238.

Bakioğlu, A. (2015). Eğitimde mentorluk. Ankara: Nobel Akademik Yayıncılık Eğitim Danışmanlık Tic. Ltd. Şti.

Balkar, B., \& Şahin, S. (2014). Aday Öğretmenlere yönelik mentorluk programının uygulanmasına ilişkin eğitimcilerin görüşü. The Journal of Academic Social Sciences, 29, 83-100.

Beltekin, N. (2010). Öğretmen yeterlilikleri, Uluslararası Öğretmen Yetiştirme ve Politikaları ve Sorunları Sетровуити (pp. 233-243). Hacettepe Universitesi, Ankara.

Brazil, T. M. (2013). An examination of stress in early childhood teachers. Unpublished Master's Thesis. California State University, Sacramento, USA.

Cantimer, G. (2008). Illköğretim okul yöneticileri ve ilköğretim müfettişlerinin mentorluk rollerine ilişkin görüşleri. Yüksek Lisans Tezi. Sakarya Üniversitesi Sosyal Bilimler Enstitüsü, Sakarya.

Creswell, J. W. (2016). Nitel araştırma yöntemleri: Beş yaklaşıma göre nitel araştırma ve araştırma deseni (3.Baskı). Ankara: Siyasal Kitabevi.

Çelik, M., \& Gündoğdu, K. (2007). Türkiye'de okul öncesi eğitimin tarihsel gelişimi. Kazım Karabekir Eğitim Fakültesi Dergisi, 1(16), 173-190.

Çelikten, M., Şanal, M., \& Yeni, Y. (2005). Öğretmenlik mesleği ve özellikleri. Sosyal Bilimler Enstitüsü Dergisi, 19(2), 207-237.

Denham, S. A., Bassett, H. H., \& Miller, S. L. (2017). Early childhood teachers' socialization of emotion: Contextual and individual contributors. Child Youth and Care Forum, 46, 805-824. https://doi.org/10.1007/s10566-017-9409-y

Ekinci, A. (2010). Aday öğretmenlerin iş başında yetiştirilmesinde okul müdürlerinin rolü. Dicle Üniversitesi Ziya Gökalp Eğitim Fakültesi Dergisi, 15, 63-77.

Elbay, S. (2015). Okul yöneticilerinin mentorluk rollerini yerine getirme düzeyleri: Kilis örneği. Yüksek Lisans Tezi. Zirve Üniversitesi Sosyal Bilimler Enstitüsü. 
Geng, G., Midford, R., \& Buckworth, J. (2015). Investigating the stress level of ealry childhood, primary and seconadry pre-service teachers during teaching practicum. Journal of Teacher Education for Sustainability, 17(1), 35-47. https://doi.org/10.1515/jtes-2015-0003

Gül, Y, E. (2015). Öğretmen yetiştirme sistemlerinin karşılaştırılması: Almanya ve Kırgızistan örneği. Uluslararası Türk Ĕ̈itim Bilimleri Dergisi, 68-83.

Işı-Ercan, Z., \& Perkins, K. (2017). Reflection for meaning and action as an engine for Professional development across multiple early childhood teacher education context. Journal of Early Childhood Teacher Education, 38(4), 342-354. https://doi.org/10.1080/10901027.2017.1394935

İlyas, E. İ., Coşkun, İ., \& Toklucu, D. (2017). Türkiye'de aday ögretmen yetiştirme modeli: izleme ve değerlendirme raporu. Siyaset, Ekonomi, ve Toplum Araştırmaları Vakfı (SETA), 51-56.

Kardos, S. M., \& Johnson, M. S. (2010). New teachers' experience of mentoring: the good, the bad, and the inequity. Journal of Education and Change, Springer, 11, 23-44. https://doi.org/10.1007/s10833-008-9096-4

Katz, L. (1972). Developmental stages of preschool teachers. The Elementary School Journal, 73(1), 50-54. https://doi.org/10.1086/460731

Katz, L. G., \& Raths, J. D. (1985). Dispositions as goals for teacher education. Teaching and Teacher Education, 1(4), 301-307. https://doi.org/10.1016/0742-051X(85)90018-6

Kelly, A. L., \& Berthelsen, D. C. (1995). Preschool teachers' experiences of stress. Teaching and Teacher Education, 11(4), 345-357. https://doi.org/10.1016/0742-051X(94)00038-8

Köse, A. (2016). Okul yöneticilerinin görüşlerine göre aday öğretmen yetiştirme sürecinin değerlendirilmesi. Abant İzzet Baysal Üniversitesi Ĕ̈itim Fakültesi Dergisi, 16(3), 924-944.

McCarthy, C., Lambert, R., \& Fitchett, P. G. (2018). Teacher stress and coping. The TESOL Enyclopedia of English Language Teaching, 1-7. https://doi.org/10.1002/9781118784235.eelt0145

M. E. B. (2013). Okul öncesi eğitim programı. T.C. Milli Eğitim Bakanlığı Temel Eğitim Genel Müdürlüğü, Ankara.

Naillioğlu K. M. (2017). Aday öğretmenlerin yetişme sürecinin değerlendirilmesi ve mentorluk önerilerinin uygulanmasina ilişkin görüşler. Doktora Tezi. Gazi Üniversitesi Eğitim Bilimleri Enstitüsü, Ankara.

Okutan, M., \& Aydoğdu, F. G. O. (2009). Adaylık eğitiminin aday öğretmenlerin görüşlerine göre değerlendirilmesi: Trabzon ili örneği. Millî Eğitim Dergisi, 183, 190-201.

Patton, M. C. (2015). Qualitative research and evaluation methods: integrating theory and practice. Library of Congress Catalogin-in-Publication Data. USA: Sage Publications, Inc.

Rust, O. F. (1994). The first year of teaching: it's not what they expected. Teaching and Teacher Education, 10, 205-217. https://doi.org/10.1016/0742-051X(94)90013-2

Seferoğlu, S. S. (2004). Öğretmen yeterlikleri ve mesleki gelişim. Bilim ve Aklın Aydınlı̆̆ında Ĕ̆gitim, 58, 40-45.

Sheridan, S. (2001). Pedagogical quality in preschool: an issue of perspectives. Göteborg Studies in Educational Sciences, Göteborg, Sweden.

Tunçbilek, M. M., \& Tünay, T. (2017). MEB aday öğretmen yetiştirme süreci uygulamasının ilgili tarafların bakış açısıyla değerlendirilmesi. Elektronik Sosyal Bilimler Dergisi, 16(61), 412-427. https://doi.org/10.17755/esosder.304683

Ulubey, Ö. (2017). Aday öğretmen yetiştirme programının değerlendirilmesi. Hacettepe Üniversitesi Ĕgitim Fakültesi Dergisi, 33(2), 480-502. https://doi.org/10.16986/HUJE.2017031014

Watkins, A. (2016). Role of the principal in beggining new teacher education. New Teacher Center, Assertion.

Yıldırım, A., \& Şimşek, H. (2016). Nitel Araştırma Yöntemleri. Seçkin Yayıncılık San. Ve Tic. A.Ş. Ankara.

\section{Copyrights}

Copyright for this article is retained by the author, with first publication rights granted to the journal.

This is an open-access article distributed under the terms and conditions of the Creative Commons Attribution license (http://creativecommons.org/licenses/by/4.0/). 